Taking stock of Rwanda's decentralisation: changing local governance in a post-conflict environment

Benjamin Chemouni

Department of International Development, London School of Economics, London, UK

Email: b.h.chemouni@Ise.ac.uk; Telephone: +44 (0) 7512737919

Dr. Benjamin Chemouni is a Fellow in the Department of International Development, London School of Economics and Political Science, Houghton Street, London WC2A 2AE, United Kingdom. 


\title{
Taking stock of Rwanda's decentralisation: changing local governance in a post-conflict environment
}

This version: 06/02/2017.

\begin{abstract}
This article takes stock of Rwanda's decentralisation by reviewing the existing evidence and putting them into perspective with the wider literature on decentralisation. It challenges the narrative that depicts the Rwandan decentralisation as a wholly negative or destabilising process by arguing that the focus of the scholarship on lack of popular participation should not ignore key dynamics that had significant stabilising effects. Yet, as the Rwandan economy and society are becoming more diversified, introduction of bottom-up mechanisms of decisionmaking will be necessary in the future to enhance the government responsiveness to evolving local needs and ensure stability in the long run.
\end{abstract}

\section{Key words}

Rwanda, Decentralisation, RPF, instability, reform sequencing, local governance.

\section{Introduction}

Started in 2000, the decentralisation in Rwanda has been extensive and wide-reaching. It has resulted in an entirely redrawn administrative map of the country, with renamed localities and significant resources and responsibilities pushed to the local level to an unprecedented extent. This has been done in three distinct phases. Phase 1, from 2000 to 2006, concentrated on reconciliation and cohesion, holding grassroots elections, and undertaking institutional and legal re-design. The prefectures became provinces, the communes below them districts (akarere). The second phase (2006 - 2011) resulted in a major institutional overhaul. The number of administrative structures was greatly reduced, from 11 provinces to 4, from 106 districts to 30. Below, sectors (umurenge) were merged, as were cells below them. A new level was created, the village. The 30 districts are currently the main local governments of the country. They are decentralised administrative units, with financial autonomy and legal personality. They oversee 416 sectors and 2148 cells (akagali) that are only deconcentrated entities of the district. The 14,837 villages (imidugudu) are not formally an administrative entity but vehicles for community mobilisation.

Furthermore, the names of all districts and of some towns were changed. Yearly performance contracts (imihigo) signed between district mayors and the President were instituted. The 
current third phase of decentralisation (2011-2016) focusses mainly with strengthening capacities at the local level and further transfers responsibilities and resources within the existing institutional framework. As the third and last phase of decentralisation is drawing to a close, the government's aim in the coming years is to consolidate the progress made especially by supporting district staff skills and deepening the fiscal decentralisation. ${ }^{1}$

As with many topics on the Rwandan post-genocide trajectory, the outcomes of decentralisation have been subject to debate. The dominant academic narrative on the Rwandan decentralisation underlines that it is not an instrument of greater citizens' participation but that it remains mainly a tool of the authoritarian centre to penetrate further in society and exercise its power in a top-down manner. In doing so, the government repeats dangerous governance patterns of the past and creates the conditions for the future return of instability. ${ }^{2}$ Yet this literature has failed to analyse the Rwandan experience in light of the larger scholarship on decentralisation in developing countries and post conflict situation. Doing so, it overlooked evidence that decentralisation can be a perilous, destabilising process and consequently fails to appreciate important progress made in Rwanda.

This article's contribution to offer an alternative assessment of Rwanda's decentralisation to the one commonly found in the literature. It challenges the dominant narrative that depicts the Rwandan decentralisation as wholly negative process, arguing that key dynamics have had significant stabilising effects. First, the Rwandan decentralisation has been essential in promoting development, making it a quite exceptional case on the African continent where the impact of decentralisation on poverty reduction has been often disappointing. ${ }^{3}$ Through tight monitoring of local governments underpinned by a result-oriented governance, and enhanced coordination of local officials, decentralisation has allowed the swift implementation of national developmental policies and significant progress in service delivery. Second, while the literature on Rwanda is justified underlining the serious issues of the lack of citizen empowerment, it however ignores the importance of sequencing in the decentralisation processes. It was important for other elements in tension with participation to be put in place first so that decentralisation could play a meaningful role in development. Finally, the article suggests that further analysis on how power is deployed territorially in Rwanda is needed. Although top-down, power might be currently exercised in a somewhat different manner from pre-1994 Rwanda, and thus has different implications in terms of a possible return of violence.

The article begins by presenting the methodology and a simple framework to assess decentralisation along two components: service delivery and poverty reduction on one hand, and governance on the other. It then turns its attention to the impact of decentralisation on service delivery and development in Rwanda, showing the mechanisms through which significant development progress could be achieved. The third section assesses decentralisation against the governance criteria. It concurs with the dominant analysis that decentralisation has so far largely failed to deliver its promise in terms of governance, but 
balances this analysis highlighting the importance of reform sequencing in the context of postgenocide Rwanda. It also suggests that the dominant analysis of state/society interface in Rwanda might fail to acknowledge some crucial ruptures with the past, potential factors of stability in the long run. The fourth section draws together and discusses the evidence presented in the previous sections. The article finally offers concluding reflections on the future of decentralisation and the conditions for its success in the long run.

\section{Assessing decentralisation}

Decentralisation can be defined as the transfer of administrative, financial and political responsibility and authority from higher (usually central) to lower levels of government. ${ }^{4}$ The expected benefits of decentralisation, although linked, can be analytically classified into two broad categories: benefits related to service delivery and poverty reduction and benefits related to governance. First, decentralisation is often embraced as an institutional arrangement to improve service delivery and poverty reduction. ${ }^{5}$ It is expected to bring services closer to the people by empowering local governments, and making services tailored to local realities. ${ }^{6}$ Allocative efficiency of public funds is expected to improve since local governments, through better access to locally specific information, are in a better position to prioritise resources more effectively than higher spheres of government. ${ }^{7}$

Under what conditions these theoretical benefits of decentralisation can materialise is much disputed however. Evidence of decentralisation as decreasing poverty or improving service delivery in developing countries is ambivalent, if not disappointing. Some main causes commonly associated with the disappointing results of decentralisation include inadequate institutional arrangements, resources and local skills. ${ }^{8}$ Additionally, local elite often captures decentralised resources and power, increasing inequities in service delivery. ${ }^{9}$ Decentralisation can also undermine budget discipline, leading local governments to engage in unconstrained expenditures because of the expectation that the centre will always bail them out. ${ }^{10}$ Finally, decentralisation can undermine economies of scale in public investment and public service production. ${ }^{11}$

In the second category, decentralisation can improve governance because it gives the population a shorter route for holding officials accountable. Instead of being accountable only to central government, local officials' careers can become more dependent on the citizens. They are thus more likely to be responsive to local needs. ${ }^{12}$ Decentralisation can deepen democracy by providing alternative route of entry for new politicians. It can also have stabilising effects by allowing voices of citizens to be heard and limit abuses of power from the centre. $^{13}$

On the other hand, the political accountability that decentralisation is supposed to foster "is particularly affected by the likelihood of corruption or capture by interest groups ${ }^{14}$ as it 
creates new opportunities for clientelism, and makes politicians, and the bureaucrats under them, less autonomous from local interest groups. ${ }^{15}$ Decentralisation can have a destabilising effect by opening new arenas of political competitions, especially in post-conflict and deeply divided societies. ${ }^{16}$

This article aims at assessing the Rwandan decentralisation against these two broad goals: service delivery and poverty reduction, and governance. The main obstacle in assessing decentralisation is the difficulty of attributing effects (e.g. better service delivery) to decentralisation itself, as many other factors are likely to come into play as well. ${ }^{17}$

Furthermore, as decentralisation is usually a nation-wide process, as is the case in Rwanda, no counterfactuals in the country are available to assess what would have happened without decentralisation. Consequently, the article does not attempt to assess quantitatively the impact of decentralisation. Rather, it focuses on the institutional arrangement and mechanisms introduced and their likely effects, and analyses to what extent decentralisation stayed clear of the risks inherent to the process, as highlighted in the literature. To do so, the common distinction between the administrative, political and financial dimensions of decentralisation are used. The article will refer to the classic distinction between deconcentration, where responsibilities are transferred to central government's local administrative units, delegation, where governmental functions are contracted to private or public entities, and devolution, where autonomous local government with elected officials are elected. ${ }^{18}$ The article is based on a review of the literature and on the author's fieldwork trips in Rwanda between 2013 and 2016. The combined duration of fieldwork in Rwanda has amounted to over one year.

\section{Decentralisation, service delivery and poverty reduction}

Service delivery and poverty reduction have improved greatly in Rwanda since $2000 .{ }^{19}$ Although inequalities remain high in the country, the GDP per capita increased of $4.8 \%$ on average per year between 2000 and $2015 .{ }^{20}$ Rwanda is one of the few countries to have reached most of its Millennium Development Goals. ${ }^{21}$ It made significant improvements in terms of service delivery. For instance, between 2000 and 2014, maternal mortality decreased from 1071 to 210 maternal deaths per 100.000 live births, infant mortality from 107 to 32 per 1,000 live birth and school net enrolment increased from $72.6 \%$ to $96.8 \%{ }^{22}$

The impact of the institutional transformation brought about by decentralisation on improving poverty reduction and service delivery needs to be demonstrated. Three main mechanisms can explain why decentralisation can be credited for much of the developmental progress locally in Rwanda.

\section{Resources and services closer to the people}

The first mechanism is that services have been brought closer to the population by providing local governments with significant resources and skills to deliver and monitor them. This is 
because the Rwandan government, unlike in other decentralisation experiences, has not shied away from transferring significant human and financial resources locally.

Districts received in the $2014 / 2015$ fiscal year $15 \%$ of the national budget, executing in total $21 \%$ of the central budget, ${ }^{23}$ putting Rwanda at the same level of countries like Uganda, which however started its decentralisation process a decade earlier. ${ }^{24}$ Rwanda's 30 district headquarters are now little governments in themselves. Following a 2014 reform, they now employ 85 staff each overseeing education, health, agriculture, infrastructure, water and sanitation, private sector development, social protection, youth sport and culture. They are in charge of the sectors (umurenge) that are the main administrative units for service delivery, supervising schools and health centres and delivering administrative documents.

The central government has also empowered this local government workforce so that it can fulfil its mandate. Empowerment first concerns skills. All districts' and some sectors' staff (including the executive secretary and the internal auditor) are required to be university graduate. The goal is not only to have skilled staff, it is also to boost their capacity to oversee effectively service providers. For instance, since 2013, directors of district health units have been required to hold a Master's degree in a move to eliminate any inferiority complex relating to education of the directors towards the medical staff (especially doctors) which could hinder effective oversight. Empowerment of local officials has also occurred in terms of salary and status. In the civil service, mayors have the rank of ministerial Permanent Secretaries (PS), district executive secretaries the rank of central state's Director General. The 416 sector executive secretaries have a rank of Director of a central ministry. They all have the corresponding salaries, except mayors who are one category below the PS on the salary scale. ${ }^{25}$ Overall, this demonstrates a genuine commitment to empower the districts in their mandate, which stands in stark contrast with the frequent reluctance of central governments elsewhere to provide local government with adequate resources in the process of decentralisation. ${ }^{26}$ As a consequence, services are closer to the population. There is no need to travel to Kigali or to the provincial capital as in the past to get administrative documents. Health centres are overseen by sectors officials and not by officials from the central administration in Kigali.

While districts have emerged as formidable implementation and delivery instruments, they remain limited planning instruments. ${ }^{27}$ The centre retains most of the power to decide what performance targets should be achieved by districts during the yearly planning consultations with the districts. Furthermore, districts have limited discretionary power on the use of funds. Close to $80 \%$ of transfers from central government are in the form of funds earmarked for precise activities, mainly related to service delivery. ${ }^{28}$ This remains however lower than in Uganda for instance. ${ }^{29}$ Furthermore, a large proportion of discretionary funds (block grants) is absorbed by salary payment in Rwanda. 
Nonetheless, it would be wrong to analyse districts as only informally deconcentrated implementation agencies from the centre. Consultation with the centre for planning occurs in an institutionalised manner, where districts can assert their views on the choice of activities and targets, although the view of the centre often, yet not always, prevail. Districts have a significant leeway in terms of infrastructure construction. They are in charge of planning and procurement. For instance, districts entirely manage school construction, choosing the location of the new schools and the contractor. For local economic development infrastructure (markets, handicraft centres, slaughter houses...), districts are free to decide what to build and where to build using their capital block grant envelope. Districts also remain free to determine the spending of their own locally-raised revenues. Sectors are increasingly empowered as they can now procure infrastructure and goods as well.

\section{Norm of result-oriented governance}

Decentralisation of resources has been paralleled with the promotion of a norm of resultoriented governance. The main instrument for that is the yearly mayoral performance contract (imihigo), which has led to increased pressure on the bureaucracy and on local politicians to achieve the central government's ambitious targets. The extremely high turnover of district mayors in Rwanda is a testimony to the importance of performance as a criterion of politicians' rotation. Since 2006, when the local administration was redesigned and the imihigo implemented, only two mayors managed to serve their two full five-year terms without being ousted from their seat. ${ }^{30}$ Overall, the top-down pressure from the centre, epitomised in the imihigo system, has resulted in a culture of result delivery at the lowest level of the state apparatus. ${ }^{31}$ However, the narrowness of imihigo indicators, coupled with the pressure to achieve them, has created perverse incentives. They include blunt, harsh policy implementation by local officials, more eager to reach their narrowly defined targets, rather than a focus on meeting the local population's needs. This can lead to coercion to get policy implemented, such as fining, destroying property, confiscating livestock, denying administrative document to noncompliant citizens. ${ }^{32}$ Imihigo also create incentives to cook or "technicate" (guteknica in Kinyarwanda) local governance performance numbers. However, the educational effects on local officials of result-oriented governance in the context of low capacity of post genocide Rwanda should not be underestimated. This culture "of getting things done" that has trickled down in the state apparatus is credited in different case studies for much developmental results in sectors such as health or education for instance. ${ }^{33}$

\section{Decentralisation as solving collective action problem.}

The third mechanism through which decentralisation has supported economic development and service delivery is enhanced coordination of local state services. Coordination of local officials in a centralised, or merely deconcentrated, bureaucracy can be difficult as all bureaucrats do not report to the same line ministries. In Rwanda, responsibilities were not simply transferred from line ministries to local offices (which would amount to deconcentration), they were all gathered under the responsibility of the district governments, solving collective action problems associated with service delivery. ${ }^{34}$ Districts pay the salaries 
of doctors, nurses and teachers and oversees health centres, hospital and schools. As a consequence, the production of services is eased by the collaboration of different services. As one informant said, the district is "a conductor that has authority on everyone". ${ }^{35}$ For instance, as observed in the Southern Province, sensitisation in schools to the community-based health insurance (mutuelle) is facilitated by the fact that both educational and health services, and the targets they have to reach, are the responsibilities of the districts.

This "coordination effect" also comes into full play when development is co-produced with the population. First, districts are better able to get the population involved to co-produce services and infrastructure, for instance by becoming community health workers, building radical terraces to fight erosion or fix feeder roads through communal works (umuganda). In the absence of decentralisation, this can be hindered by the lack of coordination between local authorities, in charge of mobilising the population, and line ministries. Second, the decentralisation of services has increased the possibility for citizens to monitor service delivery through, for instance, joining a health committee overseeing a health centre. These different processes are well summarised by Chambers and Golooba-Mutebi when they argue that, among the factors explaining significant improvement in maternal health,

the existence of a collaborative space within which local actors come together is also important. Advisory and oversight committees which bring together service providers and local authorities, function and play an important role in ensuring that local actors are working towards the same objectives and pulling in the same direction. ${ }^{36}$

\section{Decentralisation and Governance}

The scholarship on the Rwandan local state nearly unanimously maintains that the impact of decentralisation on local governance is overall negative. Scholars argue that decentralisation has created the condition for future instability and violence because it does not provide space for popular participation while making the state penetrating always deeper in society and extending its control. ${ }^{37}$ Such assessment should not however ignore key dynamics in the Rwandan decentralisation that have significant stability effects.

\section{Decentralisation: a cause of future violence?}

The political space at the local, as in the central, level is greatly restricted. Districts mayors' elections are indirect, the result of four tiers of elections starting at cell level, giving ample space for the centre to intervene. ${ }^{38}$ Local leaders are mainly drawn from the ranks of the ruling RPF -as of March 2015, all mayors but one were RPF ${ }^{39}$ - which means that the RPF has power to make and un-make careers. As a result, the Rwandan decentralisation has hardly produced a shorter route for holding officials accountable. It has also not proved to be a route for new politicians to enter politics, as the ruling RPF holds the role of gatekeeper centrally. 
Consequently, the Rwandan decentralisation is often analysed as dispatching rather than decentralizing political power, which would create a conducive ground for the return violence. ${ }^{40}$ This pervasive diagnostic in the literature, well-articulated in Niamh Gaynor's article in this issue, deserves further examination before offering some qualifications to it.

The argument is that the nature of the Rwandan decentralisation, advanced in the administrative and financial sphere but limited politically, reinforces the ubiquity and strength of an authoritarian state by maintaining top-down structures of power. By doing so, it may reproduce what Uvin has designated as "structural violence".$^{41}$ The concept, borrowed from Galtung, refers to the situation where human beings" "realizations are below their potential realizations" ${ }^{\prime \prime 2}$ and when this situation is not directly created by individuals but results from a structure, e.g. inequality of power or unequal access to opportunities. Uvin argued that the "humiliation of top-down development" ${ }^{\text {"3 }}$ compounded by the aid industry made it "almost impossible for ordinary people's voices to be heard." ${ }^{44}$ In 1994, this was a crucial contributing factor to the genocide as it "provoked a need for scapegoating among ordinary people [while] the existence of long-standing racism allowed parts of the elite to use this need to build a genocidal movement." ${ }^{45}$ Currently, the maintenance of top-down planning and officials' sometimes harsh implementation measures, coupled with the little progress in political decentralisation, would reproduce such structural violence. This kind of decentralisation, by denying voice while achieving performance at an excessive social cost could potentially lead to re-emergence of instability. ${ }^{46}$

\section{Some stabilising effects of the Rwandan decentralisation}

This dominant narrative linking the Rwandan decentralisation and potential return to conflict must however be qualified.

\section{Trade-off and sequencing}

First of all, the persistence of top-down structure of power and lack of popular participation has to be balanced against the destabilising effects of political decentralisation, especially given the country's lack of capacity and recent history of mass violence. The tangible headways in the decentralisation's administrative and financial dimensions, while the political side is lagging behind, can also decrease the probability for the whole process to be derailed.

Although relatively few studies investigate the impact of sequencing on the success of decentralisation, they all underline that sequencing is important. ${ }^{47}$ Consequently, snapshot analyses of the Rwandan decentralisation highlighting the excessive upward accountability of officials might not consider a key cause of success on the long run: adequate sequencing of reforms. 
In the administrative sphere, putting in place solid systems and skills locally before progress on the financial and political front reduces the risk of failure of the decentralisation process. ${ }^{48}$ Political and financial decentralisation without adequate capacity can be unproductive. For instance, Loayza et al. found that in Peru, poor local capacity was a bigger constraint to local government effectiveness than budget allocation, difficulties to identify local needs or political economy considerations. ${ }^{49}$ Tight oversight of officials by the centre, and restriction on their discretionary use of funds might consequently be a necessary first step in the process of decentralisation while capacity is weak. For instance, deconcentration of services, i.e. their transfer to lower levels with providers and supervisors still accountable to the centre, before their effective devolution can decrease the risk of their disruption when full decentralisation is undertaken. The tradition of deconcentrated services in Indonesia for example explains why the country managed to maintain continuous service delivery despite its "big bang" approach to decentralisation in the early 2000s. Conversely, the absence of deconcentrated services prior to full decentralisation in Latin America accounts for the fragility and reversal of the process in several countries. ${ }^{50}$ In Rwanda, the effective decentralisation of service delivery, but the limited decentralisation of their planning, and the tight control of the centre on finance can be viewed as a healthy process rather than an inherent shortcoming of decentralisation.

In the financial sphere, putting in place a robust and comprehensive fiscal framework, and ensuring hard budget constraints constitute pre-requisite to minimise corruption and galloping deficit leading to macro-economic instability. ${ }^{51}$ In this light, the continuous deepening of fiscal decentralisation in Rwanda in parallel with the limited (albeit increasing) discretion in the expenditure of district funds can also be interpreted as a healthy process rather than solely a lack of empowerment of districts by the centre.

In the political sphere of decentralisation, in their race for newly decentralised power, local groups are likely to capture public resources, instrumentalise political identities, resort to patronage, and exacerbate historical divisions. Decentralisation not only becomes unable to deliver its developmental promises, but also exacerbates social tensions. ${ }^{52}$ In Rwanda, the risk of centrifugal forces associated with political decentralisation has been especially acute since 1994 as, besides the deep division in society after the horrors of the genocide, the distinction between the Hutu majority population and the new Tutsi ruling elite overlapped to a certain extent with the rural/urban divide. ${ }^{53}$

In the light of the broader literature on decentralisation, the reluctance of the Rwandan government not to give too much financial, administrative and political leeway to districts can be re-assessed. Despite the dangers of decentralisation, there was political will to begin the process. The abysmal level of officials' capacities, the tradition of state centralisation, and deep social divisions created a significant risk of derailment. To avoid this prospect, the government gave more power to the local level, yet kept tight control of planning and resource allocation to ensure that decentralisation will not hinder, but rather serve, its 
developmental ambitions. Crucially, the fear of losing control of the decentralisation process is compounded by the fact that fast-paced development has been embraced as the prime legitimation strategy of the Tutsi-led RPF. This embrace has been all the more powerful as the RPF political legitimacy was very low since, after reaching power during the genocide targeting the Tutsi, it ruled over a Hutu majority exposed for decades to an anti-Tutsi ideology.

The rare instances of recentralisation of state functions amidst the general trend of decentralisation in Rwanda exemplify the awareness of the government that decentralisation can potentially be a double-edged sword that can support, but also derail its development project. Transferring responsibilities locally cannot, in the government's mind, occur at the expenses of state capacity. When districts were obviously unable to manage some of the new responsibilities devolved to them, these responsibilities have been recentralised. The recent examples of tax collection and management of the Rwandan Community-based insurance ( $\mathrm{CBHI}$, also called mutuelles) are revealing in this respect. Regarding the former, whereas the district used to be in charge of collecting all revenues locally, property, business, revenue and rental tax collection have been recentralised in the hand of the Rwanda Revenue Authority (RRA) in 2014 following the disappointing performance of districts. ${ }^{54}$ Similarly, the CBHI has been historically managed at sector-level. Yet, a series of scandals about mismanagement of funds and lack of capacity have led to the transfer of the responsibility of the $\mathrm{CBHI}$ to the Rwandan Social Security Board (RSSB) to increase professionalism and strengthen budget accountability. ${ }^{55}$ These examples are also further testimony of the importance of sequencing decentralisation, building capacity first before empowering the local level.

\section{Qualifying structural violence?}

The second main qualification to the poor governance track record of the Rwandan decentralisation concerns the exact magnitude of the "structural violence". Structural violence, while real, must be seen against the benefits that the top-down exercise of power created in terms of development. As mentioned, the concept of structural violence is the situation where individuals cannot reach their full potential. While decentralisation has not allowed citizens to engage in decision-making, or voice their aspirations and exasperation, it has, on the other hand, contributed to Rwandans getting closer to their full potential through better access to education, reduced maternal and child mortality, access to locally planned and built markets or handicraft centres, to name but a few.

Furthermore, the extent to which structural violence in Rwanda resembles the past, and might consequently produce the same effect, can be challenged. Undoubtedly, the ethos of policy implementation is problematic in Rwanda given its harsh nature, and the lack of popular consultation. Yet, the portrayal in the literature of the Rwandan decentralisation as the continuity of pre-1994 patterns of governance, likely to produce similar effect's, should be further interrogated. First, it remains unclear if current structures of local governance can be 
seen as the continuity of the pre-1994 era, producing similarly "structural violence". Especially, the unconstrained power of local officials, heralded as a main cause of structural violence, might deserve further research. For instance, is the structure of incentives facing current district mayors equivalent to ones of the bourgmestres of the Habyarimana regime? Undoubtedly, mayors as former bourgmestres owe their position more to the ruling party than to elections, and their loyalty flows towards the top rather than the population. Yet, mayors' power might be more constrained than those of the bourgmestre of pre-1994 Rwanda. Their selection, as demonstrated elsewhere, has as much to do with political loyalty as performance. ${ }^{56}$ Top local officials in Rwanda apparently are not above the law. A telling example was the resignation and arrest, widely covered by the media in late 2014 and early 2015 , of three mayors (and several other officials) over inflating the mutuelles enrolment numbers for a better score at the imihigo evaluation. ${ }^{57}$

The exact nature of bottom-up pressures on local officials in Rwanda in general, and in comparison to their pre-1994 counterparts in particular, can also be further interrogated. For instance, media is often cited by local officials as playing a crucial role in putting pressure them. As explained by a district health officer, "the community calls on the radio to say that something is not working [que quelque chose ne va pas] and if I can't explain it to the mayor, there's going to be trouble [ça chauffe!]. ${ }^{58} \mathrm{~A}$ vice mayor interviewed concurred: the media "are killing us [...] we are joking but we say that one should close the journalism schools." ${ }^{59}$ Directors of hospital receive training in how to handle the media and avoid scandal. ${ }^{60}$ While media is tightly monitored by the state in Rwanda, it does not mean that some freedom of expression is not selectively allowed, not to debate politics and national policies indeed, but to support the implementation of policies and ensure quality service delivery.

Such a role of the media is supported by the fact that a national policy encourages all local government officials to be easily accessible to the population and media. For example, local officials must have their photographs and their phone numbers on the door of their offices so they can be called anytime by anyone. ${ }^{61}$ Walking in any local (and national) government buildings in Rwanda revealed that this measure is systematically enforced. Furthermore, the phone numbers and e-mails of all presidents of district councils, district executive secretaries and district agronomists were public on the website of the Rwanda Association of Local Government Authorities (RALGA). ${ }^{62}$ This indicates a general concern to make the bureaucracy more accessible to the people.

These observations suggest that the interface between state and society might not be as blunt as elsewhere suggested. More research is needed using a comparative perspective to understand whether local officials in the post-genocide state are as free in their exercise of power as their counterparts of the Second Republic era given the requirements for performance and accessibility they have to meet. In other words, the local officials under the RPF government subject to a dense web of formal and informal monitoring and evaluations of 
their performance might be less of the "little gods" than Habyarimana's prefects and bourgmestres were, with the favourable consequences this can have on in terms of "structural violence".

\section{Discussion}

At first sight, the Rwandan decentralisation can be assessed as having tangible benefits in terms of service delivery and local economic development while producing detrimental effects regarding governance. Indeed, it has not yielded its promise of greater citizens' participation while the top-down pressure on officials has pushed some to resort to coercion for policy implementation, fostering popular resentment. However, evaluating decentralisation must take into account the constraints inherent to the post-conflict period and the cost of "doing nothing". In other words, assessment of the Rwandan decentralisation must be as much about its actual effects as about counterfactuals. i.e. about what would have happened if it would have occurred differently or not at all.

Without decentralisation, such development progress in Rwanda would have been unlikely, while issues of popular participation would not have been any better. The issue of authoritarianism is arguably not an issue of decentralisation itself but a broader one pertaining to the nature of the political regime. Decentralisation could be said to have a negative impact as it has reinforced the pressure on local officials to implement policy, thus creating incentive for them to resort to coercion. Yet, had the state remained as centralised, the political elite would have still embraced development as a legitimation strategy and put pressure officials to deliver the national developmental project. Structural violence does not need a decentralised state to occur, as pre-1994 Rwanda amply demonstrates. The only key difference is that, by being decentralised, more pressured officials are deployed closer to the people. While this issue is undeniable, it must be balanced against what such process has allowed in terms of development. It also requires further interrogating the extent to which counter dynamics for holding officials accountable to the population in terms of policy implementation and service delivery are emerging.

Current decentralisation in Rwanda can also be criticised on the basis that a different form of decentralisation, not breaking its promise of citizen empowerment, could have emerged. Yet, against the backdrop of the academic evidence of the centrifugal forces inherent to decentralisation, and given the deep divisions running through Rwanda's society, and the low capacity of the state and its scarce resources, the space for a radical alternative form of decentralisation to emerge was arguably limited. At least incremental decentralisation, with the centre keeping a strong hand on the process, has allowed the government to pull the hat trick of simultaneously developing the country, staying clear of the pitfalls of corruption, local 
elite capture and lack of capacity, while creating properly financed and staffed structure of decentralised government.

\section{Conclusion: the way forward}

This article offered an alternative view of the decentralisation process in Rwanda to what is usually found in the literature. It argued that, given the constraints faced by Rwanda after the genocide, and more generally in the light of the experience of decentralisation in poor and/or post conflict countries, depicting the Rwandan decentralisation in a more favourable light is warranted. To do so, it first sought to uncover the causal mechanisms between decentralisation and developmental progress in Rwanda. It highlighted that decentralisation had a positive impact on development through the significant transfers of resource and skills to the local level, the coordination mechanisms it created, and the result-oriented norms it promoted in the local bureaucracy. In the governance sphere, the article qualified the overall negative narrative on the destabilisation effects of decentralisation. Undoubtedly, how local governance operates in Rwanda has worrying shortcomings. Yet, these shortcomings can also be explained by the double imperative the Rwandan elite faced: deliver development to support its political legitimation while maintaining stability in the context of extreme social divisions following the genocide. In this context, a decentralisation of responsibilities and resources paralleled with the safeguard of the central government's influence can be seen as important for decentralisation to succeed in the long run.

This argument bears some methodological implication. Given the exceptional character of the recent Rwandan history and trajectory, assessment should adopt a comparative perspective. Comparisons across time is needed, whether to underline and question the repetition of dangerous governance patterns, or simply to keep in mind the extraordinary situation the countries faced not so long time ago. Comparison across space is also required. Examining the scholarship on decentralisation experiences in developing countries reveals that, unlike what has happened in many African countries, Rwanda's decentralisation has been associated with poverty reduction and absence of elite capture. Assessment should also take counterfactuals into account. Decentralisation cannot be solely evaluated against some ideal criteria of development and governance. It must be also assessed relative to what would have been the cost of not decentralising, and what is the space for radically alternative forms of decentralisation to emerge. The article argues that the current form of decentralisation is better than the maintenance of centralisation. It also suggests that the recent history of the country makes a strong argument for a significant degree of control from the central government. 
Does this means that such a situation should persist indefinitely and that incremental improvements in state/citizen should be secondary because of the past and of local governments' limited capacities? It should not. As stated by Smoke, "to argue that such problems justify maintaining centralisation is equivalent to condoning permanent authoritarian regimes in countries where people are poorly educated and unfamiliar with democracy. ${ }^{\prime 63}$ The risk represented by the lack of voice for citizen is real. Such situations can be explainable, as argued here, in the exceptional situation of post-genocide Rwanda, but it is dangerous in the future. While a strong centre might be the condition of a successful decentralisation initially, as the last phase of decentralisation comes to an end in 2016, further empowerment of citizens is a condition of its ultimate success now that the institutions staffed with increasingly capable officials are in place. The government must understand that what has made decentralisation a success so far, i.e. the preservation of a strong role of the centre, could also lead to its future failure. As the Rwandan economy and society are becoming more differentiated, the introduction of bottom-up mechanisms of decision-making will be necessary to enhance the government responsiveness to evolving and increasingly differentiated local needs and expectations. Planning public activities from the top is efficient only in a very low-skills and resource-constrained environment, as in the case of the postgenocide period. Yet, the preservation of the predominant role of the centre will lead to increasing inefficiency. A case can epitomise this point. As part of the flagship, and costly, policy of one-laptop per child, aiming at providing pupils with a basic laptop to teach them IT skills, laptops were delivered to districts. Yet, many computers have simply never been opened and used, as highlighted in the Office of the Auditor's General Report. ${ }^{64}$ The cause is simple. Bureaucrats at the centre considered it would be an excellent initiative, without wondering if this was meeting real local needs and if any teacher knew how to use a laptop. Asking districts what they think would have helped to identify early on the limits of the programme design, or helped to put in place accompanying measures, such as adequate teachers' training. This mundane example is revealing of the limit of an exclusively top-down model of development and the diminishing returns it will produce.

The ultimate question is if the ruling elite, caught between the anxiety of avoiding any risks inherent to decentralisation and their need to create fast development for political legitimation, will engage on this path. This is not impossible. If development is so important for elite legitimation, the government may realise that it will not be able to develop the country without more bottom-up system of planning in order to make the local governments more responsive to the population needs. In addition, the growing resources and skills of local governments should make the ruling elite more trusting of local system and potentially willing to give districts more leeway to articulate local needs. If this does not happen, any effort towards development will be doomed by ever diminishing returns and the rise of popular discontent. 


\section{Bibliography}

Ansoms, An. "Faces of rural poverty in contemporary Rwanda: Linking livelihood profiles and institutional processes." PhD Diss., University of Antwerp, 2009.

Bardhan, Pranab. "Decentralization of governance and development." The Journal of Economic Perspectives 16, no. 4 (2002): 185-205.

Bardhan, Pranab, and Dilip Mookherjee. "Capture and governance at local and national levels." The American Economic Review 90, no. 2 (2000): 135-139.

Bahl, Roy W., and Jorge Martinez-Vazquez. Sequencing fiscal decentralization. Vol. 3914. World Bank Publications, 2006.

Beswick, Danielle. "Managing Dissent in a Post-genocide Environment: The Challenge of Political Space in Rwanda." Development and Change 41, no. 2 (2010): 225-251.

Bigdon, Christine, and S. Hettige. "Local governance and conflict management." South Asia Institute, University of Heidelberg, 2003.

Booth, David. Development as a collective action problem: addressing the real challenges of Africa Governance. ODI: Africa Power and Politics Programme, 2012.

Bucagu, Maurice, Jean M. Kagubare, Paulin Basinga, Fidèle Ngabo, Barbara K. Timmons, and Angela C. Lee. "Impact of health systems strengthening on coverage of maternal health services in Rwanda, 2000-2010: a systematic review." Reproductive health matters 20, no. 39 (2012): 50-61.

Chambers, Victoria, and Frederick Golooba-Mutebi. Is the bride too beautiful? Safe motherhood in rural Rwanda. ODI: Africa Power and Politics Programme Research Report 4, 2012.

Chemouni, Benjamin. "Explaining the design of the Rwandan decentralization: elite vulnerability and the territorial repartition of power." Journal of Eastern African Studies 8, no. 2 (2014): 246-262.

Conyers, Diana. "Decentralisation and Service Delivery: Lessons from Sub-Saharan Africa." IDS bulletin 38, no. 1 (2007): 18-32.

Crook, Rchard and Allan Sverrisson. Decentralisation and Poverty Alleviation in Developing Countries: A Comparative Analysis or, Is West Bengal Unique?, Working Paper 130, Brighton: Institute of Development Studies, 2011. 
Crook, Richard C. "Decentralisation and poverty reduction in Africa: the politics of local-central relations." Public administration and development 23, no. 1 (2003): 77-88.

Faguet, Jean-Paul. “Decentralization and governance." World Development 53 (2014): 2-13.

Falleti, Tulia G. "A sequential theory of decentralization: Latin American cases in comparative perspective." American Political Science Review 99, no. 03 (2005): 327-346.

Fjeldstad, Odd-Helge. Decentralisation and corruption. A review of the literature. Working Paper 2004: 10 Chr. Michelsen Institute, 2004.

Galtung, Johan. "Violence, peace, and peace research." Journal of peace research 6, no. 3 (1969): 167-191.

Gaynor, Niamh. "'A nation in a hurry': the costs of local governance reforms in Rwanda." Review of African Political Economy 41, no. sup1 (2014): S49-S63.

Hasselskog, Malin. "Participation or What? Local Experiences and Perceptions of Household Performance Contracting in Rwanda." Forum for Development Studies, vol. 43, no. 2 (2016): 177-199.

Hasselskog, Malin, and Isabell Schierenbeck. "National policy in local practice: the case of Rwanda." Third World Quarterly 36, no. 5 (2015): 950-966.

Huggins, Chris. "Agricultural policies and local grievances in rural Rwanda." Peace Review 21(3) (2009): 296-303.

Ingelaere, Bert. "Peasants, power and ethnicity: A bottom-up perspective on Rwanda's political transition." African Affairs 109, no. 435 (2010): 273-292.

Ingelaere, Bert. "What's on a peasant's mind? Experiencing RPF state reach and overreach in post-genocide Rwanda (2000-10)." Journal of Eastern African Studies 8, no. 2 (2014): 214-230.

Loayza, Norman V., Jamele Rigolini, and Oscar Calvo-González. “More than you can handle: decentralization and spending ability of Peruvian municipalities." Economics \& Politics 26, no. 1 (2014): 56-78.

Local Government Finance Commission, Review of Local Government Financing Financing Management and Accountability for Decentralized Service Delivery. Kampala: Republic of Uganda, 2012.

MINALOC. Governance and Decentralization Sector Strategic Plan 2013/14-2017/18. Kigali: Republic of Rwanda, Ministry of Local Government, 2013. 
NISR. Statistical Yearbook, 2015 Edition. Kigali: National Institute of Statistics of Rwanda, Republic of Rwanda, 2015.

OAG, Report of the Auditor General of State Finances for the Year Ended 30 June 2015. Kigali: Office of the Auditor General, Republic of Rwanda, 2016.

Prud'Homme, Remy. "The dangers of decentralization." The World Bank Research Observer 10, no. 2 (1995): 201-220.

Robinson, Mark. "Introduction: Decentralising service delivery? Evidence and policy implications." IDS bulletin 38, no. 1 (2007): 1-6.

Rodden, Jonathan, Gunnar S. Eskeland, and Jennie llene Litvack. Fiscal decentralization and the challenge of hard budget constraints. Cambridge: MIT press, 2003.

Purdeková, Andrea. “'Even if I am not here, there are so many eyes': surveillance and state reach in Rwanda." The Journal of Modern African Studies 49, no. 03 (2011): 475-497.

Reyntjens, Filip. Political governance in post-genocide Rwanda. Cambridge: Cambridge University Press, 2013.

Rondinelli, Dennis A., James S. McCullough, and Ronald W. Johnson. "Analysing decentralization policies in developing countries: a political-economy framework." Development and Change 20, no. 1 (1989): 57-87.

Sánchez, Fabio and Mario Chacón, Conflict, State and Decentralization: From Social Progress to an Armed Dispute for Local Control, 1974-2002, Working Paper no. 70, Crisis States Programme, LSE, London, 2005.

Smoke, Paul. "Decentralisation in Africa: goals, dimensions, myths and challenges." Public administration and development 23, no. 1 (2003): 7-16.

Smoke, Paul. "Rethinking decentralization: Assessing challenges to a popular public sector reform." Public Administration and Development 35, no. 2 (2015): 97-112.

Sommers, Marc. Stuck: Rwandan youth and the struggle for adulthood. Athens: University of Georgia Press, 2012.

Treisman, Daniel. The architecture of government: Rethinking political decentralization. Cambridge: Cambridge University Press, 2007.

Uvin, Peter. Aiding violence: The development enterprise in Rwanda. West Hartford: Kumarian Press, 1998. 
Verpoorten, Marijke. Growth, Poverty And Inequality In Rwanda: A Broad Perspective, WIDER Working Paper 2014/138 Helsinki: UNU-WIDER, 2014.

Williams, Timothy. Oriented towards action: the political economy of primary education in Rwanda. ESID Working Paper No. 64. Manchester, UK: The University of Manchester, 2016 Wunsch, James S. “Decentralization, local governance and 'recentralization' in Africa." Public Administration and Development 21, no. 4 (2001): 277-288.

World Bank. World Development Report 2004: Making Services Work for Poor People. Washington, DC: World Bank, 2003.

World Bank. Decentralization in client countries: an evaluation of World Bank support, 19902007. Washington, DC: World Bank, 2008.

World Bank, World Development Indicators, 2016. http://data.worldbank.org/datacatalog/world-development-indicators (accessed 28/08/2016)

\section{Endone}

${ }^{1}$ MINALOC, Governance and Decentralization Sector.

2 E.g. Gaynor, this issue; Ingelaere, "Peasants, power and ethnicity"; Ingelaere, "What's on a peasant's mind?"; Purdeková, "'Even If I Am Not Here"; Reyntjens, Political governance in post-genocide Rwanda, 260-261; and Sommers, Stuck, 228-229.

${ }^{3}$ Conyers, "Decentralisation and Service Delivery"; and Crook, "Decentralisation and Poverty Reduction in Africa".

${ }^{4}$ World Bank, Decentralization in Client Country, 3.

${ }^{5}$ World Bank, Making Services Work for Poor People.

${ }^{6}$ E.g. Treisman, The Architecture of Government, 11.

${ }^{7}$ E.g. World Bank, Decentralization in Client Country, 8. 
8 Conyers, "Decentralisation and Service Delivery"; Crook, "Decentralisation and Poverty Reduction"; Crook \& Sverrisson "Decentralisation and Poverty Alleviation"; Robinson "Introduction: Decentralising"; and Wunsh, "Decentralization, Local Governance".

${ }^{9}$ Bardhan, "Decentralization of Governance and Development";

${ }^{10}$ Roden et al., "Fiscal Decentralization”

${ }^{11}$ Prud'homme, "The Dangers of Decentralization".

${ }^{12}$ Faguet, "Decentralisation and Governance", 5; and World Bank, Making Services Work for Poor People, 89.

${ }^{13}$ Faguet, "Decentralisation and Governance",

14 Bardhan, "Decentralization of Governance and Development", 192. See also Prud'homme, "The Dangers of Decentralization"; and Bardhan \& Mookherjee, "Capture and governance at local and national levels"; for a review, see Fjeldstad "Decentralisation and corruption".

${ }^{15}$ Bardhan, "Decentralization of Governance and Development"; and Prud'homme, "Danger of Decentralization."

${ }^{16}$ Jackson, this issue.

${ }^{17}$ Smoke, “Rethinking Decentralization", 108.

${ }^{18}$ Rondinelli, McCullough, and Johnson, "Analysing decentralization policies".

${ }^{19}$ Verpoorten, "Growth, Poverty and Inequality".

${ }^{20}$ World Bank, World Development Indicators.

${ }^{21}$ NISR, Statistical Yearbook, 5-7.

22 Ibid.

${ }^{23}$ Source: Ministry of Finance and Economic Planning

${ }^{24}$ Local Government Finance Commission, Review of Local Government Financing, 24.

${ }^{25}$ Presidential Order $N^{\circ} 53 / 01$ of 19/08/2015 establishing the job classification and the salary index grid in public service. 
${ }^{26}$ E.g. Wunsh, “Decentralization, Local Governance”.

${ }^{27}$ See also Hasselskog and Schierenbeck, "National policy in local practice".

${ }^{28}$ For the year 2011/2012. MINALOC, Governance and Decentralization Sector, 13.

${ }^{29}$ In Uganda, $85-90 \%$ of the funds are earmarked. Local Government Finance Commission, Review of Local Government Financing, b.

30 They are the mayors of Gisagara District, Southern Province, and Rulindo district, Northern Province. The number of mandates for mayors is limited to two, which means that they could not run for the 2016 elections.

31 Chemouni, "Explaining the design of the Rwandan decentralization", 251; Hasselskog, "Participation or What?", 187.

32 Huggins, "Agricultural Policies"; Chemouni "Explaining the design", 250.

33 e.g. Bucagu et al. "Impact on Health System Strengthening", 57-8; and Chambers and Golooba-Mutebi, "Is the Bride"; and Williams, "Oriented towards action".

${ }^{34}$ Although some exceptions exist. In agriculture, some agricultural services are delivered by the Rwandan Agricultural Board (RAB), an agency from the Ministry of Agriculture. On conceptualising development, and notably service delivery, as a collective action problem, see Booth, "Development as a collective action problem".

35 Interview with family planning and maternal health specialist, International NGO, 23/05/2013, Rwanda, Kigali, translated from French.

${ }^{36}$ Chambers and Golooba-Mutebi, "Is the Bride".

37 Gaynor, this issue; Ingelaere, "Peasants, power and ethnicity"; Ingelaere, "What's on a peasant's mind?”; Purdeková, “'Even If I Am Not Here”; Reyntjens, Political governance in post-genocide Rwanda, 260-261; and Sommers, Stuck, 228-229.

${ }^{38}$ Citizens elect the cell councils, which elects the sector councils, which then elect the district council, that finally elect the mayor. Chemouni, "Explaining the design of the Rwandan decentralization". On the political space at the national level, see Beswick "Managing Dissent in a Post-genocide Environment" and Reyntjens, Political governance in postgenocide Rwanda. 
${ }^{39}$ The only non-RPF mayor was from the Socio-Democrat Party (PSD) mayor of Ngoma district, in Eastern Province.

${ }^{40}$ E.g. Purdeková, “'Even If I Am Not Here”; and Sommers, Stuck, 228-229

${ }^{41}$ Uvin, Aiding Violence.

${ }^{42}$ Gatlung, "Violence, peace and peace research", 138.

${ }^{43}$ Uvin, Aiding Violence, 130

${ }^{44}$ Ibid., 135.

45 Ibid., 138.

${ }^{46}$ Gaynor, this issue; Gaynor, "A nation in a hurry"; Ingelaere, "Peasants, power and ethnicity"; Ingelaere, "What's on a peasant's mind?"; Purdeková, "'Even If I Am Not Here”; Reyntjens, Political governance in post-genocide Rwanda, 260-261; and Sommers, Stuck, 228-229.

${ }^{47}$ Bahl and Martinez-Vazquez, "Sequencing Fiscal Decentralization"; and Falleti, "A Sequential Theory of Decentralization".

${ }^{48}$ Bahl and Martinez-Vazquez, "Sequencing Fiscal Decentralization".

49 Loayza, Rigolini and Calvo-González, "More Than You Can Handle”. See also Bahl \& MartinezVazquez 2006: 29.

${ }^{50}$ Bahl and Martinez-Vazquez, "Sequencing Fiscal Decentralization", 5-6.

${ }^{51}$ Ibid. 29.

52 e.g. Sanchez \& Chacon, 'Conflict, State and Decentralization"; Bigdon \& Hettige, "Local Governance and Conflict Management"; Jackson, this issue.

${ }^{53}$ Ansoms, "Re-Engineering Rural Society", 295.

54 The New Times, "Local govts surrender tax collection to RRA" 04/03/2014.

${ }^{55}$ The New Times, "Mutuelle: Why health scheme was moved to pensions body", 11/03/2014.

${ }^{56}$ Chemouni, "Explaining the Design”. 252-255. 
${ }^{57}$ The New Times, "How probe uncovered the rot in 'Mutuelle de Sante'”, 03/02/15.

${ }^{58}$ Interview with district health director, Southern Province, 13/06/2013. Translated from the French.

${ }^{59}$ Interview with a vice-mayor, Southern Province, 12/06/2013. Translated from the French.

${ }^{60}$ Interview with official in the General Directorate of Planning and Monitoring \& Evaluation, Ministry of Health 13/06/2013.

${ }^{61}$ The requirement was the same at national level.

${ }^{62}$ http://www.ralgarwanda.org/index.php?id=162. Accessed 28 August 2016.

${ }^{63}$ Smoke, "Decentralisation in Africa", 11.

${ }^{64}$ e.g. Rwanda Focus, "Reboot needed: After 7 years, One Laptop Per Child program remains a dream to public schools", 28/04/2016; and OAG, Report of the Auditor General, 62-63. 